\title{
SEASONAL SWING IN MORTALITY IN ENGLAND AND WALES
}

\author{
BY \\ ATH. P. KANELLAKIS \\ Department of Bacteriology and Immunology, Athens School of Hygiene
}

The very detailed tables of deaths in England and Wales which are published annually by the RegistrarGeneral permit a close examination of the variation in mortality that occurs month by month. It can be studied separately for each sex, at different ages, and for the numerically important causes of death. For the purpose of the present study the deaths that took place in each month in the 5 years $1952-56$ were added together. They were then adjusted to allow for the varying length of the calendar month and expressed as a percentage of the deaths occurring throughout the whole 5 years. The variability of these percentages has been measured by the coefficient of variation. This variability, together with the months of maximum and minimum mortality, and the ratios of one to the other, is set out by age and sex in Table I. The monthly changes are shown in more detail in Fig. 1 A and B (overleaf).

VARIABILITY BY Age AND SEX.-The seasonal swing is least marked, it will be seen, in the neo-natal period of life. At these early ages, congenital defects, birth injuries, and prematurity form the dominating causes of death and the external environment is likely to be of relatively little importance. There is, however, a sharp change in the remaining period of the first year of life. In these 11 months of age the seasonal variability is at its maximum with a coefficient of variation of 34. The coefficient then falls steadily with age until, at 55 years and above, the population reveals once more an increasing susceptibility to the winter environment and its attendant respiratory infections. The seasonal variability in the very old (75 and over) approaches that in the very young.

With one exception the sexes behave alike. The exception lies in the age group 5-14 years where the monthly variation is appreciably higher for the boy than for the girl (19 to 13 per cent.), and the month of maximum mortality for the male (August), unlike that for the female (February), is quite out of keeping with the remainder of the Table. This is the only distribution with a summer maximum. The published data do not allow the causes of death to be examined within the age groups, but there seems little doubt that accidental drowning underlies this striking age and sex disparity. The boys aged 5-14 had a greater annual death rate in 1952-56 than girls of the same age, and this excess was due mainly to deaths from violence. They had almost $2 \frac{1}{2}$ times as many deaths from accidents, and seven times as many boys were accidentally drowned -760

TABLE I

PERCENTAGE MONTHLY DISTRIBUTION OF DEATHS FROM ALL CAUSES, BY AGE. ENGLAND AND WALES, 1952-56

\begin{tabular}{|c|c|c|c|c|c|c|c|c|}
\hline \multirow{3}{*}{ Age } & \multirow{2}{*}{\multicolumn{2}{|c|}{ Coefficient of Variation }} & \multicolumn{4}{|c|}{ Month of } & \multirow{2}{*}{\multicolumn{2}{|c|}{$\begin{array}{l}\text { Ratio of Maximum to } \\
\text { Minimum No. of Deaths }\end{array}$}} \\
\hline & & & \multicolumn{2}{|c|}{ Maximum } & \multicolumn{2}{|c|}{ Minimum } & & \\
\hline & Males & Females & Males & Females & Males & Females & Males & Females \\
\hline $\begin{array}{l}\text { Under } 4 \text { wks } \\
4 \text { wks-1 yr } \\
1 \text { yr } \\
2-4 \\
5-14 \\
15-54 \\
55-74 \\
75 \text { and Over }\end{array}$ & $\begin{array}{r}8 \\
34 \\
23 \\
12 \\
19 \\
11 \\
20 \\
26\end{array}$ & $\begin{array}{r}9 \\
34 \\
23 \\
16 \\
13 \\
12 \\
18 \\
26\end{array}$ & $\begin{array}{l}\text { Feb. } \\
\text { Feb. } \\
\text { Jan. } \\
\text { Feb. } \\
\text { Aug. } \\
\text { Feb. } \\
\text { Feb. } \\
\text { Feb. }\end{array}$ & $\begin{array}{l}\text { Feb. } \\
\text { Jan. } \\
\text { Feb. } \\
\text { Feb. } \\
\text { Feb. } \\
\text { Feb. } \\
\text { Feb. } \\
\text { Feb. }\end{array}$ & $\begin{array}{l}\text { Aug. } \\
\text { Aug. } \\
\text { Sept. } \\
\text { Oct. } \\
\text { Oct. } \\
\text { Sept. } \\
\text { Aug. } \\
\text { Aug. }\end{array}$ & $\begin{array}{l}\text { Sept. } \\
\text { Aug. } \\
\text { July } \\
\text { Aug. } \\
\text { Sept. } \\
\text { July } \\
\text { Aug. } \\
\text { Aug. }\end{array}$ & $\begin{array}{l}1 \cdot 3 \\
2 \cdot 6 \\
2 \cdot 1 \\
1 \cdot 5 \\
1 \cdot 5 \\
1 \cdot 4 \\
1 \cdot 8 \\
2 \cdot 1\end{array}$ & $\begin{array}{l}1 \cdot 3 \\
2.5 \\
1.9 \\
1 \cdot 6 \\
1 \cdot 5 \\
1.4 \\
1.7 \\
2 \cdot 1\end{array}$ \\
\hline All Ages & 20 & 21 & Feb. & Feb. & Aug. & Aug. & $1 \cdot 8$ & $1 \cdot 8$ \\
\hline
\end{tabular}




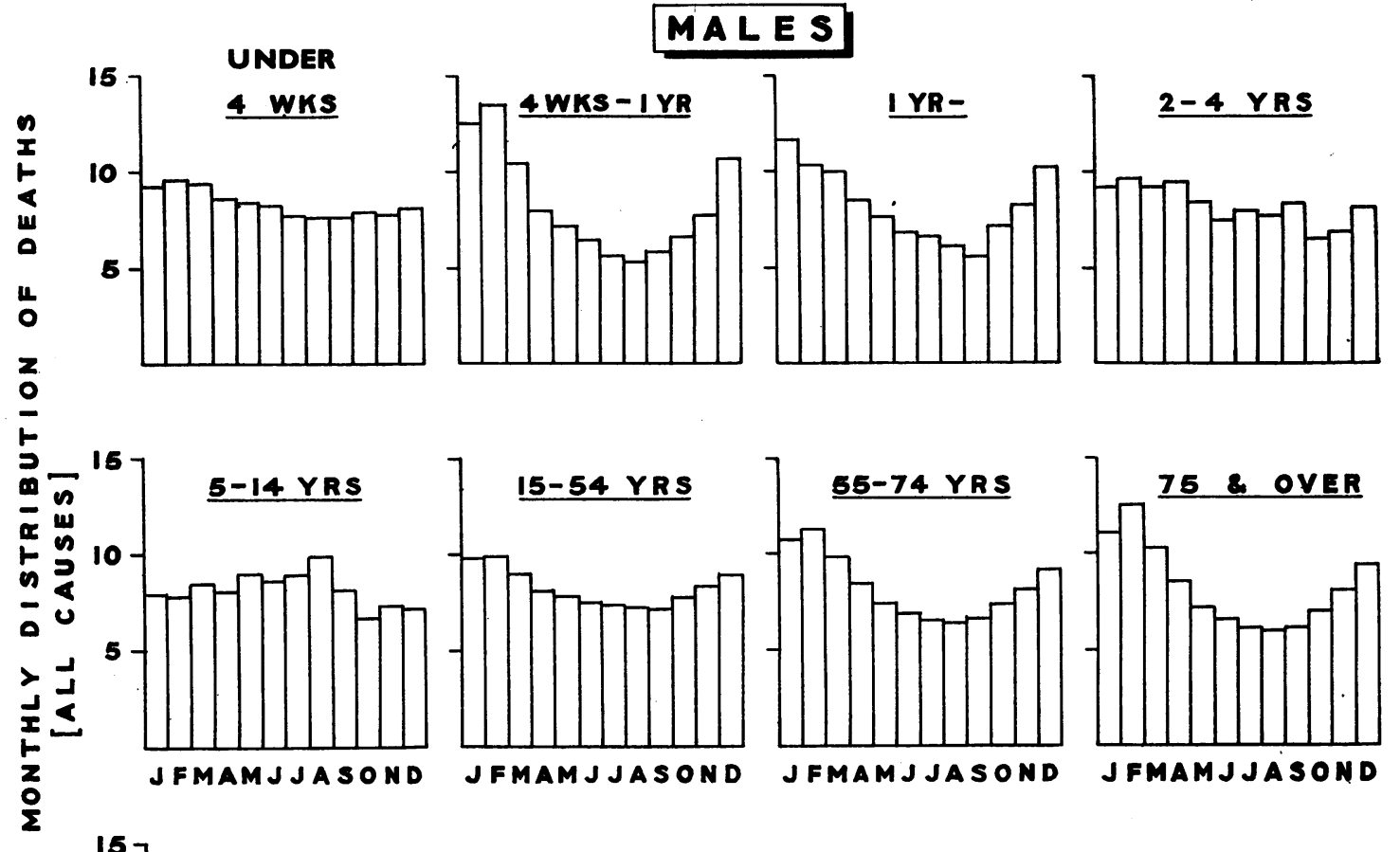

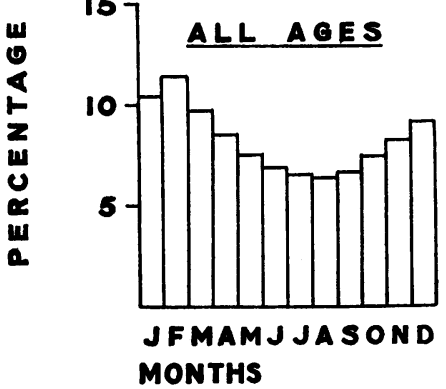

Fio. 1A.-Percentage monthly distribution of male deaths from all causes, by age. England and Wales, 1952-56.

compared with only 108 girls. The curve for girls does show some rise in the number of deaths in July and August (Fig. 1B), but the change is far less pronounced than for boys.

With this exception the predominating month for the peak of mortality in England and Wales is February. The minimum is less consistent. At all ages the rate falls in August for both sexes, but at different ages it varies from July to October. As would be expected on the large numbers concerned, the $\chi^{2}$ test shows a significant departure from linearity for each age group for each sex.

The seasonal movement at all ages can be compared with that reported by the Registrar-General in his annual report for 1925 . His table of deaths by month of occurrence had been introduced in 1921 and, as in the present study, he analysed a 5 year period, 1921-25. Since then the death rates at most ages, and particularly up to the fourth decade of life, have fallen profoundly and many causes of death have shown great changes. However, the peak of mortality those $\mathbf{3 0}$ years ago occurred, as it still does to-day, in February-27 per cent. above the meanand the minimum came, as it still does, in August22 per cent. below the mean. In the present data February was 40 per cent. above the mean and August still 22 per cent. below. The increase in the winter peak is due, one would suggest, to the ageing of the population and to the greater susceptibility to winter conditions which is shown by the old (see Table I).

The monthly distributions in 1921-25 and in 195256 are set out in detail in Table II (opposite).

In spite of the changing picture in national mortality referred to above, the distributions are remarkably similar. No comparisons by age can be made, however, since this feature was not introduced into the tabulation until a much later date.

Variability by Cause of Death.-Corresponding figures for various causes of death are given in Table III (overleaf) and are shown in more detail in Fig. 2 $A$ and $B$ (overleaf). 

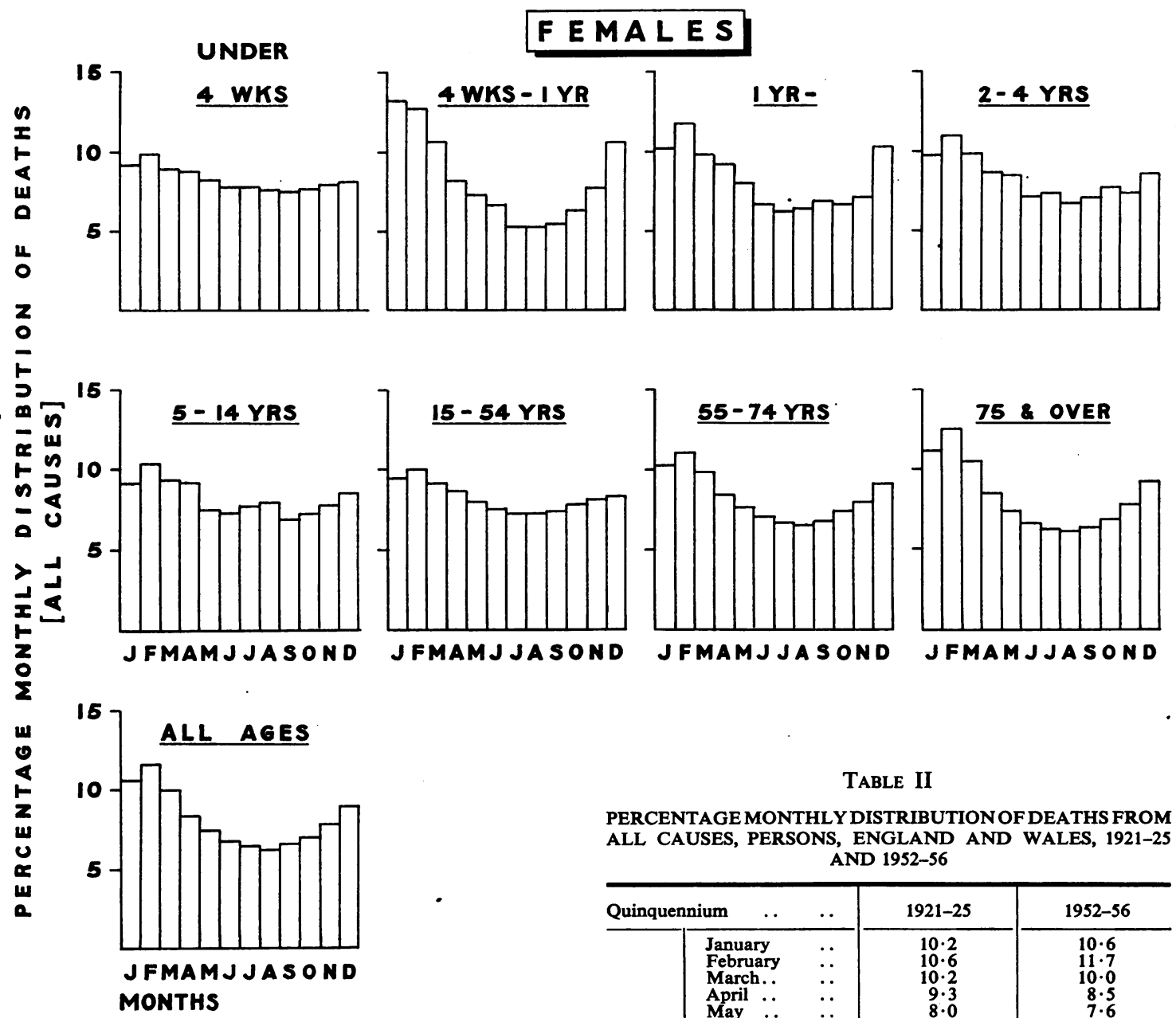

TABLE II

PERCENTAGE MONTHLY DISTRIBUTION OF DEATHS FROM ALL CAUSES, PERSONS, ENGLAND AND WALES, 1921-25 AND 1952-56

FIG. 1B.-Percentage monthly distribution of female deaths from all causes, by age. England and Wales, 1952-56.

As would be anticipated, the greatest seasonal variation is a feature of the respiratory illnessesinfluenza, pneumonia, bronchitis, asthma, and bronchiectasis.

At a lower level, quite considerable variation is shown by diseases of the heart and circulation and by diseases of the digestive system. On the other hand, there is very little variation in the month of dying with the important cancers of the lung and stomach. The maximum number of deaths from all these various causes falls mainly in February. One striking exception for both sexes lies in suicide. Here the curve rises to a peak in April. The minimum is distinctly more variable in its appearance and reveals one or two curiosities; e.g. deaths from appendicitis

\begin{tabular}{|c|c|c|c|c|}
\hline \multicolumn{3}{|c|}{ Quinquennium } & $1921-25$ & \multirow[b]{2}{*}{$\begin{array}{c}1952-56 \\
10 \cdot 6 \\
11 \cdot 7 \\
10 \cdot 0 \\
8 \cdot 5 \\
7 \cdot 6 \\
7 \cdot 1 \\
6 \cdot 6 \\
6 \cdot 5 \\
6 \cdot 7 \\
7 \cdot 3 \\
8 \cdot 1 \\
9 \cdot 3\end{array}$} \\
\hline Month & $\begin{array}{l}\text { January } \\
\text { February } \\
\text { March.. } \\
\text { April .. } \\
\text { May .. } \\
\text { June .. } \\
\text { July . . } \\
\text { August } \\
\text { September } \\
\text { October } \\
\text { November } \\
\text { December }\end{array}$ & $\begin{array}{c}\cdots \\
\cdots \\
\cdots \\
\cdots \\
\cdots \\
\cdots \\
\cdots \\
\cdots \\
\cdots\end{array}$ & $\begin{array}{l}10 \cdot 2 \\
10 \cdot 6 \\
10 \cdot 2 \\
9 \cdot 3 \\
8 \cdot 0 \\
7 \cdot 0 \\
6 \cdot 6 \\
6 \cdot 5 \\
6 \cdot 7 \\
7 \cdot 0 \\
8 \cdot 4 \\
9 \cdot 5\end{array}$ & \\
\hline Total & $\ldots$ & $\ldots$ & $100 \cdot 0$ & $100 \cdot 0$ \\
\hline
\end{tabular}

are at their lowest point in November for males and in December for females, and cancer deaths in both sexes touch their lowest point in the spring. The only sex difference of any magnitude appears to lie in accidental deaths, where at all ages the male monthly proportion is more uniform than the female.

On the $\chi^{2}$ test there was a significant departure from linearity for all causes except cancer of the stomach, appendicitis, and diseases of the liver and gall bladder, but though technically significant the deviations for many other causes were quite small. 


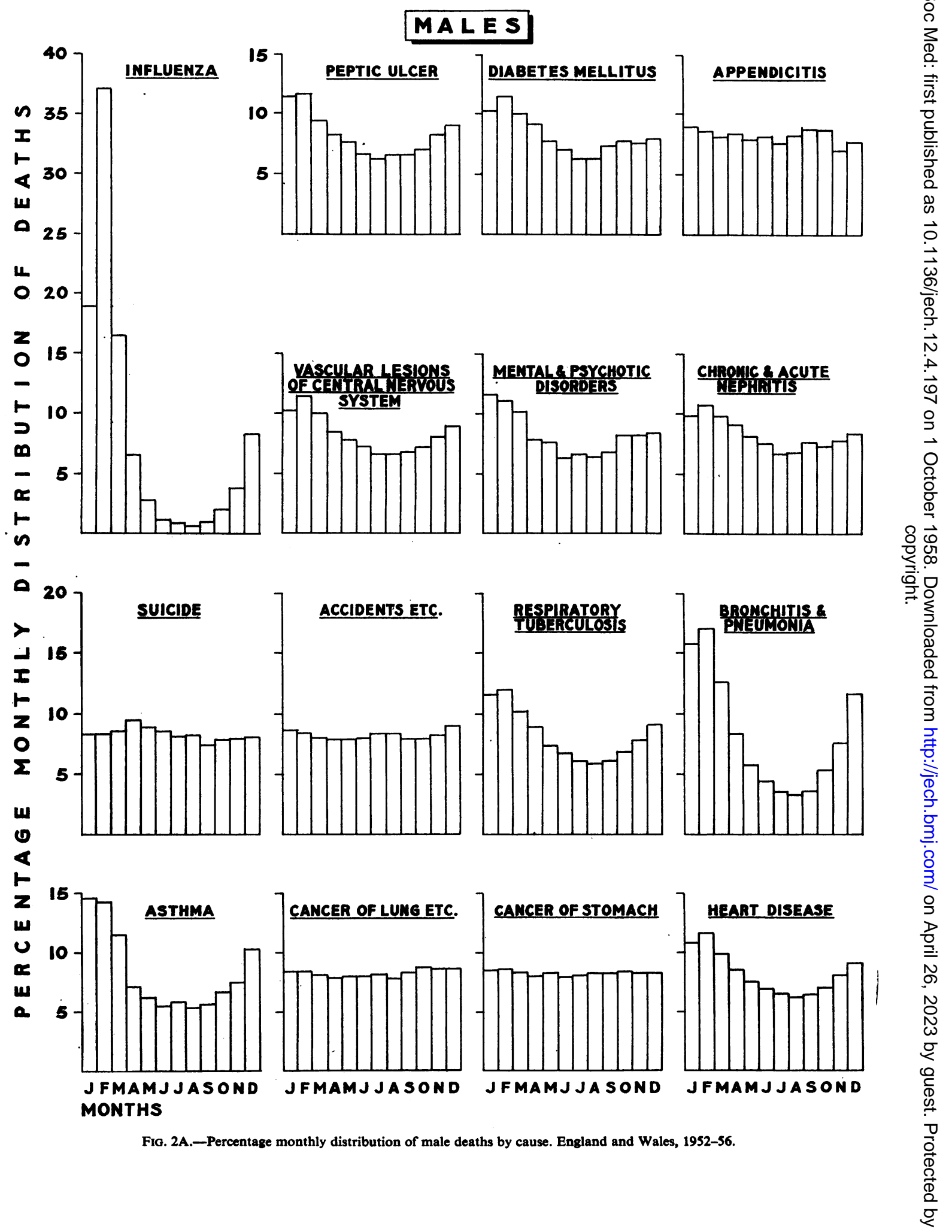




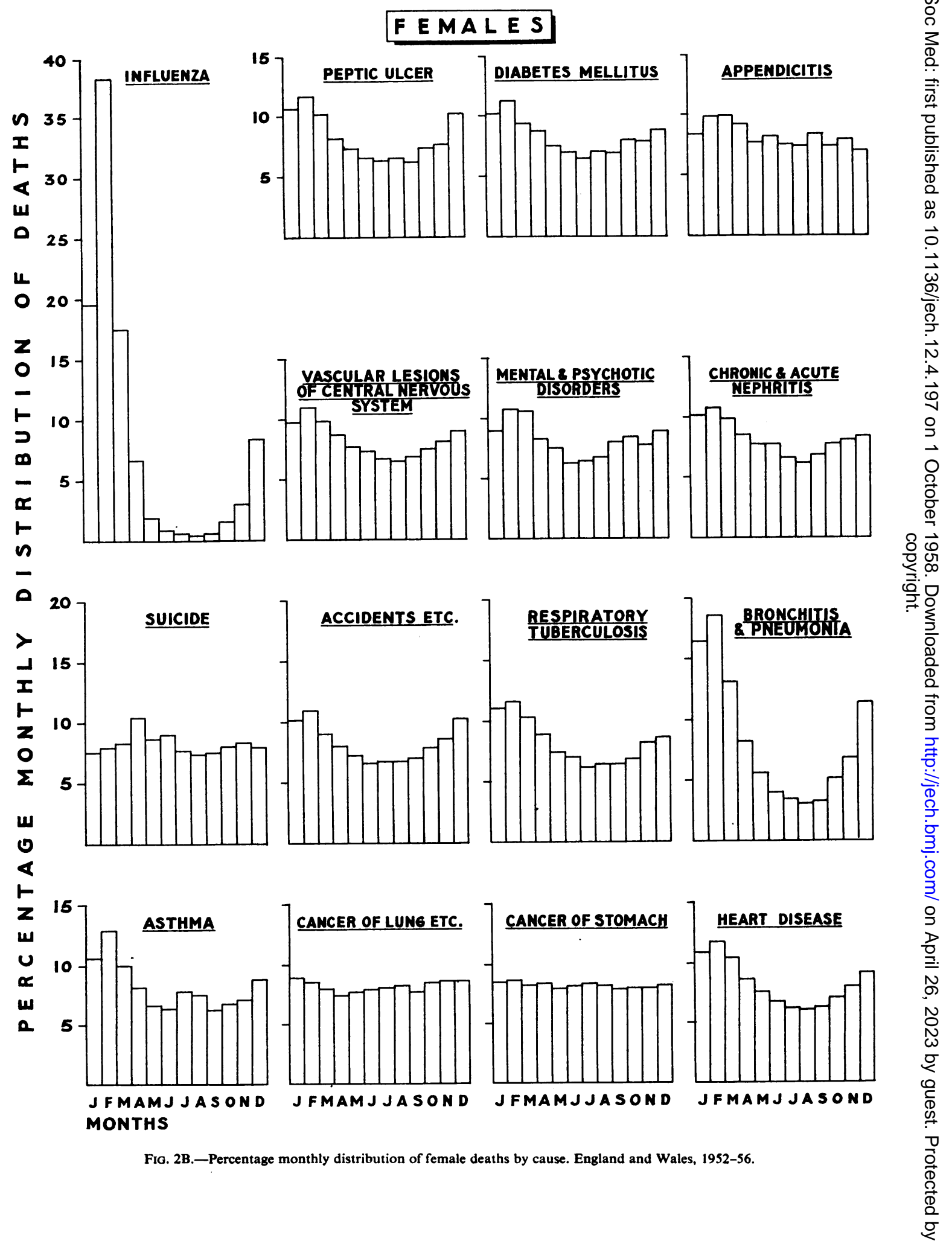


TABLE III

PERCENTAGE MONTHLY DISTRIBUTION OF DEATHS BY CAUSE ENGLAND AND WALES, 1952-56

\begin{tabular}{|c|c|c|c|c|c|c|c|c|c|}
\hline \multirow{3}{*}{$\begin{array}{c}\text { Inter- } \\
\text { national } \\
\text { List No. }\end{array}$} & \multirow{3}{*}{ Cause of Death } & \multirow{2}{*}{\multicolumn{2}{|c|}{$\begin{array}{l}\text { Coefficient of } \\
\text { Variation }\end{array}$}} & \multicolumn{4}{|c|}{ Month of } & \multirow{2}{*}{\multicolumn{2}{|c|}{$\begin{array}{l}\text { Ratio of Maximum } \\
\text { to Minimum Deaths }\end{array}$}} \\
\hline & & & & \multicolumn{2}{|c|}{ Maximum } & \multicolumn{2}{|c|}{ Minimum } & & \\
\hline & & Males & Females & Males & Females & Males & Females & Males & Females \\
\hline $480-483$ & $\begin{array}{llll}\text { Influenza } & \ldots & \ldots & \ldots\end{array}$ & 132 & 138 & Feb. & Feb. & Aug. & Aug. & $62 \cdot 0$ & $76 \cdot 6$ \\
\hline $490-502$ & Bronchitis and Pneumonia & 59 & 65 & Feb. & Feb. & Aug. & Aug. & $4 \cdot 9$ & $5 \cdot 9$ \\
\hline 526 & Bronchiectasis & 42 & 44 & Feb. & Feb. & July & July & $3 \cdot 4$ & $4 \cdot 0$ \\
\hline 241 & Asthma & 42 & 25 & Jan. & Feb. & Aug. & Sept. & $2 \cdot 7$ & $2 \cdot 1$ \\
\hline $001-008$ & $\begin{array}{c}\text { Tuberculosis of the Respira- } \\
\text { tory System }\end{array}$ & 26 & 23 & Feb. & Feb. & Aug. & July & $2 \cdot 1$ & $1 \cdot 9$ \\
\hline $420-434$ & Diseases of the Heart & 21 & 24 & Feb. & Feb. & Aug. & Aug. & $1 \cdot 9$ & $2 \cdot 0$ \\
\hline $440-447$ & Hypertensive Disease & 22 & 23 & Feb. & Feb. & Aug. & Aug. & $1 \cdot 9$ & $2 \cdot 0$ \\
\hline $290-299$ & $\begin{array}{l}\text { Diseases of the Blood and } \\
\text { Blood-forming Organs } \ldots\end{array}$ & 10 & 10 & Jan. & Feb. & Nov. & July & $1 \cdot 4$ & $1 \cdot 3$ \\
\hline $330-334$ & $\begin{array}{l}\text { Vascular Lesions affecting } \\
\text { the Central NervousSystem }\end{array}$ & 18 & 17 & Feb. & Feb. & Aug. & Aug. & $1 \cdot 7$ & $1 \cdot 7$ \\
\hline 450 & General Arteriosclerosis .. & 25 & 24 & Feb. & Feb. & Aug. & Aug. & $2 \cdot 1$ & $1 \cdot 9$ \\
\hline $300-326$ & $\begin{array}{c}\text { Mental, Psychoneurotic, and } \\
\text { Personality Disorders } \\
\end{array}$ & 22 & 19 & Jan. & Feb. & June & June & $1 \cdot 9$ & $1 \cdot 7$ \\
\hline $550-553$ & Appendicitis & 7 & 11 & Jan. & March & Nov. & Dec. & $1 \cdot 3$ & $1 \cdot 4$ \\
\hline $540-542$ & Peptic Ulcer & 22 & 22 & Feb. & Feb. & July & Sept. & $1 \cdot 8$ & $1 \cdot 8$ \\
\hline $590-594$ & Nephritis, Acute and Chronic & 15 & 17 & Feb. & Feb. & July & Aug. & $1 \cdot 6$ & $1 \cdot 7$ \\
\hline 260 & Diabetes Mellitus .. & 6 & 17 & Feb. & Feb. & Aug. & July & $1 \cdot 8$ & $1 \cdot 7$ \\
\hline 151 & Cancer of the Stomach & 2 & 3 & Feb. & Feb. & June & May & $1 \cdot 1$ & $1 \cdot 1$ \\
\hline $162-165$ & Cancer of the Lung & 4 & 6 & Feb. & Jan. & April & April & $1 \cdot 1$ & $1 \cdot 2$ \\
\hline E970-E979 & Suicide $\quad \ldots \quad \ldots$ & 7 & 10 & April & April & Sept. & Aug. & $1 \cdot 3$ & $1 \cdot 4$ \\
\hline E800-E965 & Accidents and Violence & 5 & 17 & Dec. & Feb. & April & June & $1 \cdot 2$ & $1 \cdot 6$ \\
\hline 794 & Senility & 32 & 25 & Feb. & Feb. & Aug. & Sept. & $2 \cdot 4$ & $2 \cdot 0$ \\
\hline \multicolumn{2}{|c|}{ All Causes } & 20 & 21 & Feb. & Feb. & Aug. & Aug. & $1 \cdot 8$ & $1 \cdot 8$ \\
\hline
\end{tabular}

Comparison with the Registrar-General's figures for 1921-25 reveals some interesting contrasts. The first lies in the very considerable attention that he rightly pays to deaths from the common infectious diseases of childhood-whooping cough, measles, scarlet fever, and diphtheria. To-day none of them is of sufficient quantitative importance to call for any special attention, and they do not appear at all in Table III.

In 1921-25, no cause of death showed such variation as influenza and to-day that is still true. The ratio of maximum to minimum a generation ago, was however, very distinctly less than to-day-21-fold compared with the figure of 60 to 70 in Table III. The earlier period contained two sharply epidemic years, 1922 and 1924, and these have had no parallel in recent times. The main respiratory causes, bronchitis, pneumonia, and asthma, show no appreciable change in their seasonal swing between
1921-25 and the present time. On the other hand mortality from respiratory tuberculosis shows a significantly wider swing to-day than previously. The Registrar-General shows a maximum in February which is only 1.4 times its minimum in September. Table III shows a ratio as high as 2 for both sexes combined. It would seem that, as the disease is brought under control, the deaths become more concentrated in the period of least favourable environmental circumstances.

One point to which the Registrar-General repeatedly turned in 1921-25 was the possible effects of Christmas upon the death rate. For a number of causes of death he records a December elevation in mortality followed by a January depression. This he noted, for example, with diabetesand "at no other time of year can the temptation to dietetic and other indiscretions be so great"; this he observed with heart disease (particularly that 
associated with the coronary artery)-and "Christmas is, of course, a season of excitement and overindulgence in food and drink when even sufferers from recognized heart disease may be tempted by the spirit of good fellowship into taking undue risks"; and this he also observed with aneurysm and arteriosclerosis and the peptic ulcers. Whatever the explanation-whether it is that our diseases or our habits are to-day more restrained-none of these December elevations appears in the figures for 1952-56. Fig. 2 reveals no such rise in December with a subsequent fall in January. The phenomenon has disappeared.

Finally the tendency to take one's own life in 1921-25 showed a high level through April, May, and June with a slight peak in the final month. In 1952 56 the peak falls earlier, in April, but the variation over the whole year is, compared with all causes of death, relatively small-and was equally so in 1921-25.

\section{SUMMARY}

The seasonal variability of mortality in England and Wales has been examined for the years 1952-56. The greatest variability is found at the extremes of life, in the age groups 4 weeks to 1 year and 75 years and over. The predominating peak month of mortality is February, with the month of minimum varying between July and October. Most causes of death show some degree of variation, the swing being greatest with the respiratory infections and least with cancer. Two striking exceptions to the general trend are a peak mortality for boys aged 5-14 years in August, which is due, almost certainly, to accidental drownings, and a relatively high level of suicides in the spring. There is in these modern figures no sign of the December rise in mortality from such diseases as diabetes, heart disease, and peptic ulcers, which was noted by the Registrar-General in the corresponding figures for 1921-25, and which, he suggested, was due to the excitements and indiscretions of Christmas.

I acknowledge my gratitude to Dr. W. J. Martin for much help and advice in the analysis of these figures and to Professor Bradford Hill, in whose Department at the London School of Hygiene and Tropical Medicine, and at whose suggestion, the study was undertaken during my tenure of a Fellowship awarded by the World Health Organization. 